\title{
Ultrastructural and phylogenetic data of Chloromyxum riorajum sp. nov. (Myxozoa), a parasite of the stingray Rioraja agassizii in Southern Brazil
}

\author{
Carlos Azevedo ${ }^{1,2, *}$, Graça Casall ${ }^{1,2,3}$, Patrícia Garcia ${ }^{4}$, Patrícia Matos ${ }^{5}$, \\ Leonor Teles-Grilo ${ }^{6}$, Edilson Matos ${ }^{7}$ \\ ${ }^{1}$ Department of Cell Biology, Institute of Biomedical Sciences (ICBAS/UP), University of Porto, 4099-003 Porto, Portugal \\ ${ }^{2}$ Laboratory of Pathology, Centre for Marine and Environmental Research (CIIMAR/UP), University of Porto, $4050-123$ Porto, \\ Portugal \\ ${ }^{3}$ Departmento de Ciências, Instituto Superior de Ciências da Saúde-Norte, 4585-116 Gandra, Portugal \\ ${ }^{4}$ Laboratory of Diagnostic and Pathology in Aquaculture, Federal University of Santa Catarina, 88040-970 Florianópolis, \\ SC, Brazil \\ ${ }^{5}$ Laboratory of Histology of Aquatic Animals, Federal University of Pará, 66075-110 Belém, PA, Brazil \\ ${ }^{6}$ Laboratory of Molecular Genetics, Institute of Biomedical Sciences (ICBAS/UP), University of Porto, 4099-003 Porto, \\ Portugal \\ ${ }^{7}$ Carlos Azevedo Research Laboratory, Federal Rural University of Amazonia, 66077-530 Belém, PA, Brazil
}

\begin{abstract}
We describe a new myxozoan parasite found infecting the gall bladder of the cartilaginous fish Rioraja agassizii (Rajidae) from the South Atlantic coast of Brazil. Light microscopy, scanning and transmission electron microscopy and phylogenetic data were used. Numerous irregular polysporic plasmodia externally covered by numerous microvilli containing different stages of sporogony, including free spores, were observed in bile. Ellipsoidal spores, on average $11.41 \mu \mathrm{m}$ long, $8.48 \mu \mathrm{m}$ wide and $7.32 \mu \mathrm{m}$ thick, were formed by 2 equal-sized valves, each possessing 3 to 4 (rarely 5) elevated ridges which projected from the basal portion of the spore, and joined along a sinuous $\mathrm{S}$ shaped sutural line. The basal portion of the valves bore a bundle of 33 to 37 extended tapering caudal filaments attached to the basal portion of the last ridge and basal portion of the sutural edge of the 2 valves. The caudal filaments, formed of material similar to the valves, were attached to the shell wall by a conical basis. The spores contained 4 equal-sized pyriform polar capsules $(4.5 \times 2.4 \mu \mathrm{m})$, located at the same level, each with a polar filament with 6 (rarely 7) coils. Binucleate sporoplasm was irregular in shape, with a granular matrix and dense bodies randomly distributed in a light area. Based on the shape and dimensions of the spore, on the number, position and arrangements of the surface ridges, caudal bundle of filaments, polar capsules and polar filament arrangements, as well as phylogenetic analyses using the small subunit ribosomal DNA (SSU rDNA) sequences, we propose the name Chloromyxum riorajum for this new myxozoan.
\end{abstract}

KEY WORDS: Cartilaginous fish · Chloromyxum riorajum sp. nov. • Parasite · Phylogeny · Ultrastructure

Resale or republication not permitted without written consent of the publisher

\section{INTRODUCTION}

The Myxosporea of the phylum Myxozoa is an assemblage of more than 2180 species distributed among some 60 genera (Lom \& Dyková 2006) with more species being added regularly. They have been reported from different geographic areas, mainly as parasitic and pathogenic of fish, where they are of importance in fisheries and aquaculture (Lom \& Dyková 2006). Among them, the genus Chloromyxum 
Mingazzini, 1890, the fourth largest genus of Myxozoa with 115 nominal species, is commonly coelozoic in the urinary tract and gall bladder of freshwater and marine fishes (Lom \& Dyková 2006) and in some non-fish host such as batrachian amphibians (Duncan et al. 2004, Lom \& Dyková 2006). Determining the taxonomy of the group is difficult when relying solely on light microscopy of the spore because there is only a limited number of distinct characters which can be used to separate the species. Revision of the genus has shown that ultrastructural microscopy, particularly scanning electron microscopy (SEM), provides taxonomic data that considers the pattern of the ridges on the spore surface (Lom \& Dyková 1993).

Considering the high number of Brazilian fish species (about 8000 species) (Cellere et al. 2002), the number of described parasite species is low. Little has been published on the myxosporeans, and that which has been published mainly concerns the genus Chloromyxum. From the Brazilian fauna, only 2 species $(C$. leydigi Mingazzini, 1890 and C. sphyrnae Cunha and Fonseca, 1918) have been observed by light microscopy and represented by diagrammatic drawings (Cunha \& Fonseca 1918, Pinto 1928, Gioia \& Cordeiro 1996). In South American fauna, there is another description of this genus found in the flatfish Paralichthys adspersus from the Pacific coast of the Chile (Oliva et al. 1996). Recently, on the bases of the morphological and ultrastructural data, a new species C. menticirrhi was described parasitizing a Brazilian marine teleost fish (Casal et al. 2009).

With respect to molecular data, there is information on the 18S rDNA gene for only 7 Chloromyxum species (Fiala \& Dyková 2004, Holzer et al. 2004, 2006, Hallett et al. 2006). An analysis of the small subunit ribosomal DNA (SSU rDNA) in phylogenetic studies shows that the majority of myxosporea can be divided into 2 main clades: marine and freshwater clades. However, there are exceptions to this division, notably regarding some species infecting anadromous hosts and species of the genus Chloromyxum (Fiala 2006). The present study describes $C$. riorajum sp. nov. from the gall bladder of the marine stingray Rioraja agassizii from coastal waters off Southern Brazil, making use of light microscopy (LM), SEM, transmission electron microscopy (TEM) and phylogenetic data pertaining to the $18 \mathrm{~S}$ rDNA sequence.

\section{MATERIALS AND METHODS}

The marine stingray Rioraja agassizii (Müller \& Henle, 1841) (Chondrichthyes, Rajidae) (Brazilian common name 'Raia-santa') was collected during February and March 2008 in the surf zone of Joaquina
Beach $\left(27^{\circ} 37^{\prime} \mathrm{S}, 48^{\circ} 26^{\prime} \mathrm{W}\right)$ located on the South Atlantic near the city of Florianópolis, Santa Catarina State, Brazil. After collection, 4 stingrays (30 to $52 \mathrm{~cm}$ total length) were transported alive to the laboratory, where they were anaesthetized with MS-222 (Sandoz Laboratories), and necropsied. Smears of fresh gall bladder and bile, urinary bladder, gill, liver and intestine were examined microscopically. Smears of fresh gall bladder contents, the only organ observed to be parasitized, containing free spores and plasmodia were prepared for observation by LM using Nomarski differential interference contrast (DIC) optics, and free spores were measured with an ocular micrometer adapted to the photomicroscope.

Electron microscopy. For SEM, gall bladders were teased apart to release spores. These were fixed in $5 \%$ glutaraldehyde buffered in $0.2 \mathrm{M}$ sodium cacodylate (pH 7.4) at $4^{\circ} \mathrm{C}$ for $20 \mathrm{~h}$, washed in 3 changes of the same buffer, dehydrated in an ascending ethanol series, critical point dried, coated with gold and examined in a JSM-630 SEM operated at $15 \mathrm{kV}$. After dehydration some spores were observed in a DIC microscope. For TEM, small fragments of the parasitized gall bladder and fluid bile containing plasmodia and free spores were fixed as for the SEM procedure, washed overnight in buffer at $4^{\circ} \mathrm{C}$, and post-fixed in $2 \%$ osmium tetroxide with the same buffer and at the same temperature for $3 \mathrm{~h}$, dehydrated in an ascending ethanol series followed by propylene oxide, and embedded in Epon. Semithin sections were stained with methylene blue-Azure II for LM, and ultrathin sections were double-stained with uranyl acetate and lead citrate and observed and photographed using a JEOL 100CXII TEM operated at $60 \mathrm{kV}$.

DNA isolation and PCR amplification. Several plasmodia and spores were preserved in $80 \%$ ethanol at $4^{\circ} \mathrm{C}$ before genomic DNA extraction which was performed using a GenElute ${ }^{\mathrm{TM}}$ Mammalian Genomic DNA Miniprep Kit (Sigma) following the manufacturer's instructions for animal tissue, except for incubation time. The DNA was stored in $50 \mu \mathrm{l}$ of TE buffer at $-20^{\circ} \mathrm{C}$ until used. Initial amplification of the SSU rDNA gene was achieved using the universal eukaryotic primers 18e (Hillis \& Dixon 1991) and 18r (Whipps et al. 2003). PCR was carried out in $50 \mu \mathrm{l}$ reactions using $10 \mathrm{pmol}$ of each primer, $10 \mathrm{nmol}$ of each dNTP, $2.5 \mathrm{mM}$ $\mathrm{MgCl}_{2}, 5 \mu \mathrm{l} 10 \times \mathrm{Taq}$ polymerase buffer, 1.5 units Taq DNA polymerase (Invitrogen), and $5 \mu \mathrm{l}$ of the genomic DNA. The reactions were run on a Hybaid PxE Thermocycler (Thermo Electron Corporation). The amplification program consisted of $95^{\circ} \mathrm{C}$ denaturation for $3 \mathrm{~min}$, followed by 35 cycles of $94^{\circ} \mathrm{C}$ for $45 \mathrm{~s}, 53^{\circ} \mathrm{C}$ for $45 \mathrm{~s}$ and $72^{\circ} \mathrm{C}$ for $90 \mathrm{~s}$. A final elongation step was performed at $72^{\circ} \mathrm{C}$ for $7 \mathrm{~min}$. Nested PCR was done using as template $2 \mu \mathrm{l}$ of initial PCR: $5^{\prime}$-end with the primers 
18e/MyxospecR, the central region of the gene with primers MyxospecF/ChloromyxR1 and finally the 3'end with the primers ChloromyxF1/18r (Table 1). The amplification program consisted of $95^{\circ} \mathrm{C}$ denaturation for $5 \mathrm{~min}$, followed by 30 cycles of $95^{\circ} \mathrm{C}$ for $1 \mathrm{~min}, 52^{\circ} \mathrm{C}$ for $1 \mathrm{~min}$ and $72^{\circ} \mathrm{C}$ for $2 \mathrm{~min}$. A final elongation step was performed at $72^{\circ} \mathrm{C}$ for $10 \mathrm{~min}$. Then $5 \mu \mathrm{l}$ aliquots of PCR products were electrophoresed through a $1 \%$ agarose $1 \times$ Tris-acetate-EDTA buffer gel stained with ethidium bromide.

DNA cloning and sequencing. PCR products for the SSU rDNA gene with an approximate size of $300 \mathrm{bp}$ (18e/MyxospecR), 900 bp (MyxospecF/ChloromyxR1) and 600 (ChloromyxF1/18r) were obtained from the excised band. Before cloning, the bands were purified with NucleoSpin Extract II (Macherey-Nagel). DNA was cloned into a pGEM-T Easy Vector System II (Promega) following the manufacturer's instructions. JM109 Competent Cells with high efficiency (Promega) were transformed and then 2 positive clones were selected using the blue-white colour screening method. The minipreps were carried out with a NucleoSpin Plasmid (Macherey-Nagel) according the manufacturer's instructions. The cloned inserts were confirmed by digestion with restriction enzyme EcoRI (Promega), and then they were sequenced in both directions with the universal sequencing primers T7 forward/SP6. Sequencing was done using BigDye Terminator v1.1 from the Applied Biosytems Kit, and the sequence reactions were run on an ABI3700 DNA analyzer (Perkin-Elmer Applied Biosystems).

Distance and phylogenetic analysis. To evaluate the relationship of Chloromyxum riorajum to other myxosporean species, we used 29 18SSU rDNA sequences, obtained from GenBank data: Ceratomyxa labracis (AF411472), Ceratomyxa sparusaurati (AF411471), Ceratomyxa shasta (AF001579), Chloromyxum auratum (AY971521), Chloromyxum legeri (AY604197), Chloromyxum leydigi (AY604199), Chloromyxum leydigi (DQ377710), Chloromyxum cyprini (AY604198), Chloromyxum trijugum (AY954689), Chloromyxum truttae (AJ581916), Chloromyxum sp. (AJ581917),
Enteromyxum leei (AF411334), Enteromyxum scophthalmi (AF411335), Henneguya ictaluri (AF195510), Henneguya salminicola (AF031411), Hoferellus gilsoni (AJ582062), Kudoa amamiensis (AF034638), Kudoa crumena (AF378347), Kudoa dianae (AF414692), Myxidium lieberkuehni (X76639), Myxidium truttae (AF201374), Myxidium sp. (U13829), Myxobolus bibullatus (AF378336), Myxobolus cerebralis (U96492), Myxobolus osburni (AF378338), Parvicapsula minibicornis (AF201375), Raabeia sp. (AF378352), Sphaerospora oncorhynchi (AF201373), and Zschokkella mugilis (AF411336). The corresponding sequences and GenBank/NCBI accession number of Tetracapsuloides bryosalmonae (U70623) and Buddenbrockia plumatellae (AY074915) were used as the outgroup.

Sequences were aligned as described by Azevedo et al. (2006). Alignment was made using Clustal W (Thompson et al. 1994) with MEGA 4 software (Tamura et al. 2007), with an opening gap penalty of 10 and a gap extension penalty of 4 for both pairwise and multiple alignments. Subsequent phylogenetic and molecular evolutionary analyses were conducted using MEGA 4, with the 29 rDNA sequences for myxosporidian species and the outgroup species selected. Distance estimation was carried out using the Kimura 2parameter model distance matrix for transitions and transversions. For the phylogentic tree reconstructions, maximum parsimony analysis was conducted using the close neighbour interchange heuristic option with a search factor of 2 and random initial tree additions of 2000 replicates. Bootstrap values were calculated over 100 replicates.

\section{RESULTS}

\section{Morphology of the parasite}

During a parasitological survey conduced to detect parasites it was observed that some specimens of the stingray Rioraja agassizii presented hypertrophy of the gall bladder, the bile of which contained several masses of plasmodia and numerous free spores.

Table 1. Primer sequences and location used to amplify small subunit ribosomal DNA of Chloromyxum riorajum sp. nov.

\begin{tabular}{|llccl|}
\hline Primers & Sequence $\left(5^{\prime}-3^{\prime}\right)$ & Position & Used with & Source \\
\hline 18e & CTG GTT GAT CCT GCC AGT & 1 & MyxospecR, 18r & Hillis \& Dixon (1991) \\
MyxospecF & TTC TGC CCT ATC AAC TTG TTG & 312 & ChloromyxR1 & Fiala (2006) \\
ChloromyxF1 & CTT AAA GGA ATT GAC GGA AGG & 1209 & $18 \mathrm{r}$ & Present study \\
MyxospecR & CAA CAA GTT GAT AGG GCA GAA & 332 & $18 \mathrm{e}$ & Present study \\
ChloromyxR1 & CCT TCC GTC AAT TCC TTT AAG & 1229 & MyxospecF & Present study \\
$18 \mathrm{r}$ & CTA CGG AAA CCT TGT TAC G & 1832 & 18e, ChloromyxF1 & Whipps et al. (2003) \\
\hline
\end{tabular}




\section{Light microscopy}

Numerous plasmodia and free spores were observed immersed the bile (Figs. 1 to 3). Based on the morphological aspects of the spores and particularities of the spore valves and attached caudal bundle of the tapering filamentous projections forming tails, the parasite was identified as belonging to the genus Chloromyxum as classified according to Lom \& Dyková (2006). Our results provide a description of a new species:

Phylum Myxozoa Grassé, 1970

Class Myxosporea Bütschli, 1881

Order Bivalvulida Schulman, 1959

Family Chloromyxidae Thélohan, 1892

Genus Chloromyxum Mingazzini, 1890

\section{Chloromyxum riorajum sp. nov.}

Life history stages observed: All developmental stages in the polysporic plasmodia (up to $150 \mu \mathrm{m}$ ) and free spores immersed in the bile (Figs. 1 to 3 ).

Description: Cell membrane of the plasmodia and its pseudopodia is covered by numerous microvilli (Figs. 4 \& 5). Spores are ellipsoidal to pyriform, $11.41 \pm 0.31 \mu \mathrm{m}$ long in lateral view; $8.48 \pm 0.45 \mu \mathrm{m}$ wide and $5.92 \pm$ $0.54 \mu \mathrm{m}$ thick $(\mathrm{n}=25)$ in apical view (Figs. $1 \& 2)$. Two equal-sized valves with 3 to 4 (rarely 5) surface ridges in the posterior half of the spore. Valves adhering together along a sinuous $\mathrm{S}$-like structure of the sutural line (Figs. 6 \& 7). Ridges are located on the last half of the spore and run parallel to the basal portion of the sutural ridges (Figs. 9 to 13). The ridges coalesce towards the apical pole of the spore (Figs. 9 to 11). Each valve consists of a continuous layer of external and internal dense material surrounding a middle lighter area (Figs. 6 to 8). A bundle of 33 to 37 tapering caudal filamentous projections or tails $(12.10 \pm 0.87 \mu \mathrm{m}$ long $)$ is attached to the basal part of the last ridge and sutural ridge of the 2 valves (Figs. 1, 2, 10, 12 \& 13). There were no visible junctions between the tails and the wall. The tails were formed of the same material as the valves, and had a circular cross-section measuring 0.2 to $0.3 \mu \mathrm{m}$ in diameter near the valvar insertion (Fig. 18), reducing gradually in diameter towards the end of the tail (Figs. 1, 17 \& 19). Four anteriorly pointed equal-sized pyriform polar capsules $(3.2 \pm 0.4 \mu \mathrm{m}$ long, $2.0 \pm 0.3 \mu \mathrm{m}$ wide; $\mathrm{n}=25)$ were located all on the same level within the spore (Figs. 1 \& 2); each contained 6 (rarely 7) obliquely coiled polar filament (Figs. 15 \& 20). Sporoplasm was irregular in shape with 2 nuclei randomly distributed within a granular matrix with numerous light areas where the sporoplasmosomes were hardly visible. The spore morphology is presented in schematic drawings (Fig. 20) showing the arrangement of the valvar ridges and caudal bundle of filaments and the ultrastructural details of the spore longitudinal sections.

Type host: Rioraja agassizii (Müller \& Henle, 1841) (Chondrichthyes, Rajidae).

Type locality: Joaquina Beach $\left(27^{\circ} 37^{\prime} \mathrm{S}, 48^{\circ} 26^{\prime} \mathrm{W}\right)$ on the South Atlantic coast situated near the city of Florianópolis, Santa Catarina State, Brazil.

Site of infection: Gall bladder in bile.

Prevalence: $75 \%(3 / 4)$.

Type specimens: One slide with semi-thin sections of tissues containing spores and developmental stages of hapantotype was deposited in the International Protozoan Type Slide Collection at the Smithsonian Institution Washington, DC, USA, with the acquisition number USNM 1122327. Another slide with semi-thin sections was deposited at the Laboratory of Pathology, Centre for Marine and Environmental Research, University of Porto, Porto, Portugal.

\section{Molecular analysis}

The amplified sequences were assembled, and the resulting consensus DNA sequence of the partial SSU rRNA gene, which was 1807 bp in length, was deposited in GenBank (Accession number FJ624481). In total, 29 SSU rDNA sequences, including those with the highest BLAST scores, were aligned with the Chloromyxum riorajum sp. nov. SSU rDNA sequence. The resulting alignment consisted of 1629 positions after trimming the 3 '-end (642 ambiguously aligned positions were excluded).

Based on pairwise comparisons among the SSU rDNA sequences, the maximal similarity was observed with all Chloromyxum species: C. leydigi (97.7 and $97.9 \%)$, C. auratum $(85.4 \%)$, C. cyprini $(85.2 \%), C$. truttae $(84.6 \%)$, C. trijugum $(83.8 \%)$, C. schurovi $(82.3 \%)$ and C. legeri (80.9\%) (Table 2$)$.

Maximum parsimony analysis of SSU rDNA gene sequence places Chloromyxum riorajum sp. nov. within a clade comprising almost all Chloromyxum species, with 2 exceptions: C. legeri (AY604197) and C. schurovi (AJ581917). The most closely related species is C. leydigi (AY604199, DQ377710) with $100 \%$ bootstrap support.

\section{DISCUSSION}

The morphology of the spores described in the present study, i.e. ellipsoidal spores with 2 shell valves, 4 equal-sized polar capsules and a bundle of caudal filamentous projections, shows the characters of a parasite belonging to the genus Chloromyxum (Lom \& Noble 1984, Lom \& Dyková 2006). A comparison of our results with the morphology and ultrastructural organization 

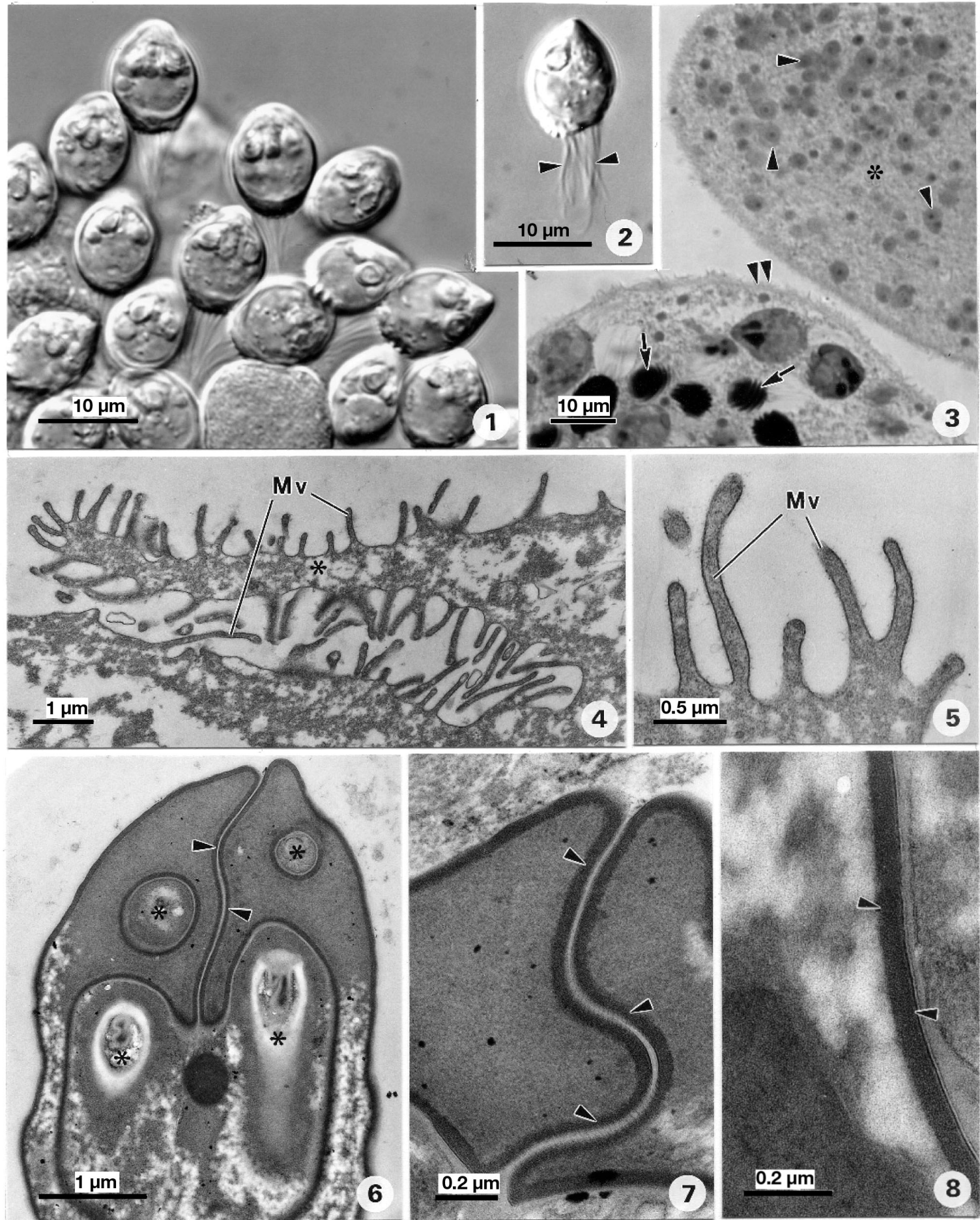

Figs. 1 to 8. Light and transmission electron micrographs of the myxosporean Chloromyxum riorajum sp. nov. from gall bladder of Rioraja agassizii. Fig. 1. Several unfixed mature spores observed using differential interference contrast (DIC). Fig. 2. A free unfixed mature spore observed under DIC showing a bundle of filamentous tails (arrowheads) attached to the base of one of the spores. Fig. 3. Semithin section showing 2 plasmodia, one of which (*) contains several of the developmental stages (arrowheads); the other one contains spores (arrows). The periphery of the plasmodia shows numerous microvilli (double arrowheads). Fig. 4. Periphery of a plasmodium (*) showing pseudopodia and several microvilli (Mv). Fig. 5. Details of the microvilli (Mv). Fig. 6. Oblique section of the apical end of a spore showing the apical end of the polar capsules $(*)$ and the sutural line (arrowheads). Fig. 7. Detail of the longitudinal section of the apical region of the S-like sutural line (arrowheads). Fig. 8. Detail of the dense internal layer of the valve (arrowheads) 

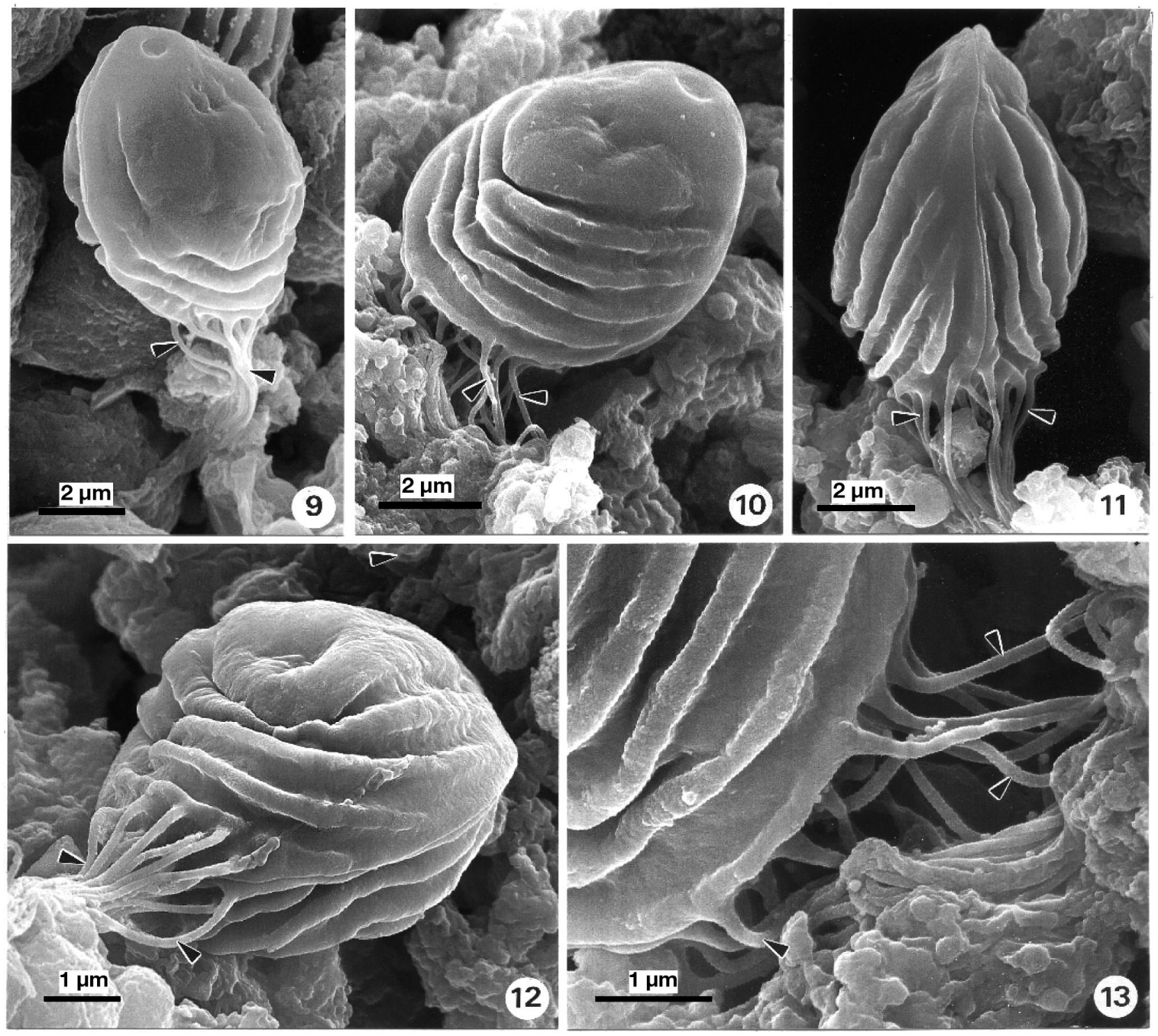

Figs. 9 to 13. Scanning electron micrographs of Chloromyxum riorajum sp. nov. spore morphology. Note particularly the bundle of filaments (arrowheads), as well the organization of the ridges

of previously described species of this genus, shows that the morphology is similar, which consequently confirms that this parasite belongs to this genus (Lom \& Noble 1984, Lom et al. 1988, Baska 1990, 1993, Molnár 1992, Shul'man \& Ieshko 2003, Hallett et al. 2006, Lom \& Dyková 1992, 2006), although few of the previously described species have attached caudal filaments.

Amongst the 115 recognized species of this genus, only Chloromyxum leydigi Mingazzini, 1890 (Pinto 1928, Gioia \& Cordeiro 1996), C. ovatum and C. transversocostatum (Kuznetsova 1977) have attached filaments (Lom \& Dyková 2006). Our species differed from these 3 species, i.e. the C. leydigi spore has sutural edge projections at the apex shell valves bearing 7 elevated ridges each; $C$. ovatum has large spores with different patterns of surface ridges, while C. transversocostatum differs from these 2 species in that it has a spore with transversal concentric surface ridges.
Recently, Kovaljova (1988) described 4 new species of the genus Chloromyxum (C. dogieli, C. lissosporum, C. schulmani and C. striatellus) from several cartilaginous fishes captured off the Atlantic coast of Africa. This description was based on diagrammatic drawings. However, it is particularly difficult to compare the present species with the species described in the Kovaljova (1988) study, because their data consisted soley of spore dimensions and drawings showing the distribution and position of the surface ridges. No references were made to the bundle of filaments shown in the drawings in the figures. However, these structures appear to be very different to those of the parasite described here.

The genus Chloromyxum has also been previously reported in South American aquatic fauna. Two species described in Brazilian fauna (C. leydigi and $C$. sphyrnae) (Gioia \& Cordeiro 1996) and another one in the urinary bladder of flatfish Paralichthys adspersus 

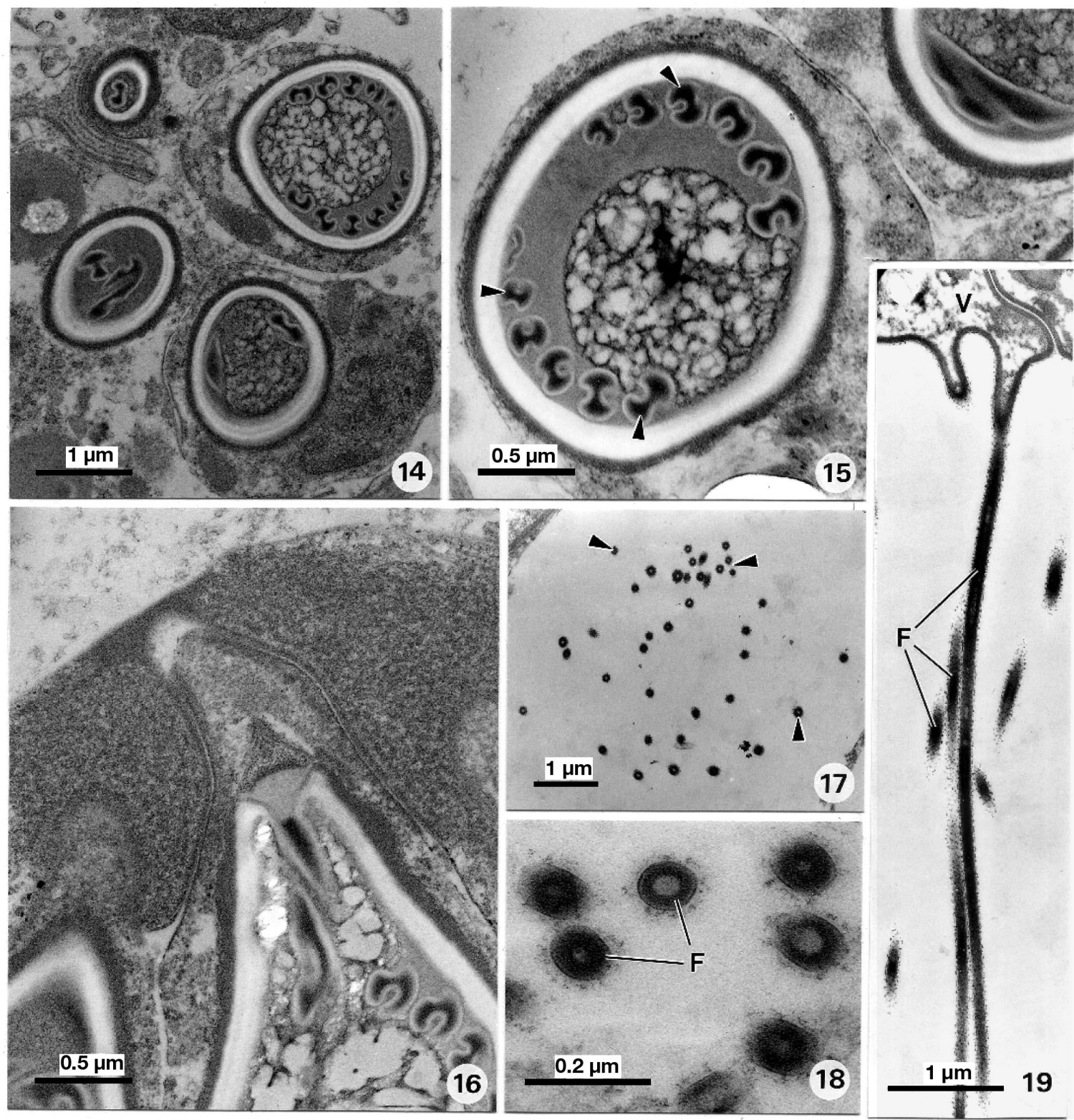

Figs. 14 to 19. Transmission electron micrographs of the myxosporean Chloromyxum riorajum sp. nov. from the gall bladder of $R i$ oraja agassizii. Fig. 14. Transverse section at the apical region of the 4 polar capsules. Fig. 15. Detail of a transverse section of a polar capsule showing different sections of a polar filament (arrowheads). Fig. 16. Longitudinal section of the apical zone of a polar capsule. Fig. 17. Transverse section of a bundle of 37 filaments (arrowheads). Fig. 18. Transverse sections showing details of several filaments $(\mathrm{F})$. Fig. 19. Longitudinal and oblique sections of several filaments (F), one of which is attached to the valve (V)

from the Pacific coast of the Chile (Oliva et al. 1996) were described by use of LM only and represented by diagrammatic drawings. Recently, C. menticirrhi spores, which do not have external filaments attached to the wall, were described on the basis of SEM and TEM studies (Casal et al. 2009).

Morphological aspects, such as the surface structure of the spore, the different patterns of spore ridges and the caudal bundle of 33 to 37 filaments (number never referred to in other species) which is attached to the more basal ridge and suture line of the Chloromyxum spore wall, which differentiate only in some species, are important characteristics which can be used to distinguish Chloromyxum species (Lom \& Dyková 1993, 2006).

The external organization of the present species is clearly very different from that of all other Chloromyxum spp. previously discussed, including those for 

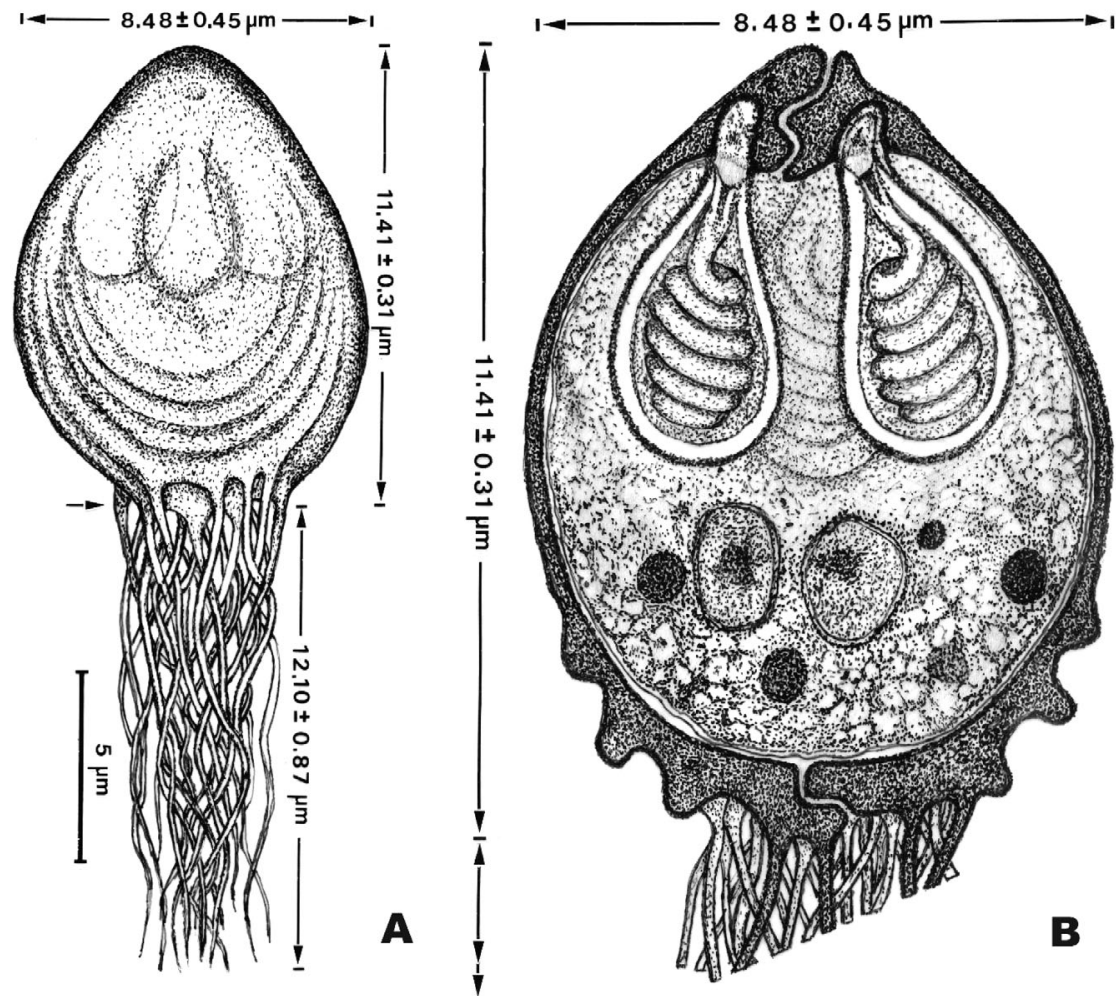

Fig. 20. Spore of Chloromyxum riorajum sp. nov. from the gall bladder of Rioraja agassizii. (A) Morphological aspect of the spore as observed under differential interference contrast (DIC), showing the basal bundle of filamentous tails attached to the valves. (B) Longitudinal section (frontal view) with special emphasis on the polar capsules and basal bundle of the filamentous tails

which a bundle of filamentous projections and ridge ornamentations on the spore valves have been reported. A comparison of the spore morphology of all Chloromyxum spp. which have tailed spores showed that there are similarities between $C$. riorajum and $C$. leydigi. However, C. riorajum differs from C. leydigi in that the former have larger spores and polar capsules, as well as different patterns of surface ridges. Moreover, the bundle of filamentous tails of $C$. riorajum differs from that of $C$. leydigi, because it has a large number of filaments and is longer.

All morphological and ultrastructural aspects are useful for the description of a new species despite the fact that of some them such as caudal appendages are

Table 2. Comparison of some small subunit ribosomal (SSU) rDNA sequences: percentage of identity (above diagonal) and pairwise distance (below diagonal) obtained by Kimura 2-parameter analysis. C.: Chloromyxum; M.: Myxidium; S.: Sphaerospora

\begin{tabular}{|c|c|c|c|c|c|c|c|c|c|c|c|c|}
\hline & $\begin{array}{c}C . \\
\text { riorajum }\end{array}$ & $\begin{array}{c}C . \\
\text { leydigi } 1\end{array}$ & $\begin{array}{c}C . \\
1 \text { leydigi } 2\end{array}$ & $\begin{array}{c}C . \\
\text { auratum }\end{array}$ & $\begin{array}{c}C . \\
\text { cyprini }\end{array}$ & $\begin{array}{c}C . \\
\text { truttae }\end{array}$ & $\begin{array}{c}C . \\
\text { trijugum }\end{array}$ & $\begin{array}{c}\text { C. } \\
\text { schurovi }\end{array}$ & $\begin{array}{c}C . \\
\text { legeri }\end{array}$ & $\begin{array}{c}M . \\
\text { truttae }\end{array}$ & $\begin{array}{l}\text { Myxidium } \\
\text { sp. onco }\end{array}$ & $\begin{array}{l}\text { S. } \\
\text { orhynchi }\end{array}$ \\
\hline C. riorajum (FJ624481) & & 97.9 & 97.7 & 85.4 & 85.2 & 84.6 & 83.8 & 82.3 & 80.9 & 82.8 & 81.9 & 81.7 \\
\hline C. leydigi 1 (DQ377710) & 0.021 & & 99.4 & 86.0 & 85.7 & 85.2 & 84.3 & 82.6 & 81.2 & 83.3 & 82.5 & 81.9 \\
\hline C. leydigi 2 (AY604199) & 0.023 & 0.004 & & 85.9 & 85.6 & 85.2 & 84.3 & 82.6 & 81.1 & 83.3 & 82.5 & 81.9 \\
\hline C. auratum (AY971521) & 0.146 & 0.140 & 0.141 & & 99.8 & 97.7 & 91.8 & 91.8 & 88.4 & 91.3 & 91.3 & 92.3 \\
\hline C. cyprini (AY604198) & 0.148 & 0.143 & 0.143 & 0.002 & & 97.4 & 91.6 & 91.6 & 88.1 & 90.9 & 90.9 & 92.0 \\
\hline C. truttae (AJ581916) & 0.154 & 0.148 & 0.148 & 0.023 & 0.026 & & 92.1 & 91.6 & 88.6 & 90.9 & 90.9 & 92.0 \\
\hline C. trijugum (AY954689) & 0.162 & 0.157 & 0.157 & 0.082 & 0.084 & 0.079 & & 90.5 & 86.2 & 95.5 & 95.9 & 89.9 \\
\hline C. schurovi (AJ581917) & 0.177 & 0.174 & 0.174 & 0.082 & 0.084 & 0.084 & 0.105 & & 87.9 & 88.5 & 88.5 & 92.3 \\
\hline C. legeri (AY604197) & 0.191 & 0.188 & 0.189 & 0.116 & 0.119 & 0.114 & 0.138 & 0.121 & & 85.8 & 84.8 & 89.9 \\
\hline M. truttae (AF201374) & 0.172 & 0.167 & 0.167 & 0.087 & 0.089 & 0.089 & 0.045 & 0.115 & 0.142 & & 97.7 & 87.6 \\
\hline Myxidium sp. (U13829) & 0.181 & 0.175 & 0.175 & 0.087 & 0.089 & 0.089 & 0.041 & 0.115 & 0.152 & 0.023 & & 88.1 \\
\hline S. oncorhynchi (AF201373) & 0.183 & 0.181 & 0.181 & 0.077 & 0.080 & 0.080 & 0.101 & 0.077 & 0.101 & 0.124 & 0.119 & \\
\hline
\end{tabular}


not a phylogenetic character. Unfortunately, with the exception of Chloromyxum leydigi, there is no SSU rDNA information for the other Chloromyxum species with caudal appendages. Apparently, the habitat, the host and the location of infection are the characteristics that have been used for species classification.

A BLAST search using SSU rDNA sequence data found only 7 Chloromyxum spp. available in GenBank: All species, except C. leydigi (AY604199) isolated from the gall bladder of Torpedo marmorata caught in the Mediterranean Sea (Fiala \& Dyková 2004) and C. leydigi (DQ377710) from the gall bladder of Centroscymnus coelolepis caught in the North Atlantic (Fiala 2006), infect freshwater fishes. C. cyprini (AY604198) and C. legeri (AY604197) were found in the gall bladder of Hypophthalmichthys molitrix and Cyprinus carpio, respectively, from the Czech Republic (Fiala \& Dyková 2004). C. auratum (AY971521) and C. trijugum (AY954689) were found in the gall bladder of Carassius auratus and Pomoxis nigromaculatus, respectively, from Oregon, USA (Hallett et al. 2006). C. truttae (AJ581916) was found in the gall bladder epithelium and C. schurovi (AJ581917) in kidney tubules of Salmo salar in Scotland (Holzer et al. 2004). We obtained an almost complete SSU rRNA gene sequence with $1807 \mathrm{bp}$.

Our analysis of the phylogenetic relationship for maximum parsimony is in concordance with previous cladograms (Fiala \& Dyková 2004, Fiala 2006, Holzer et

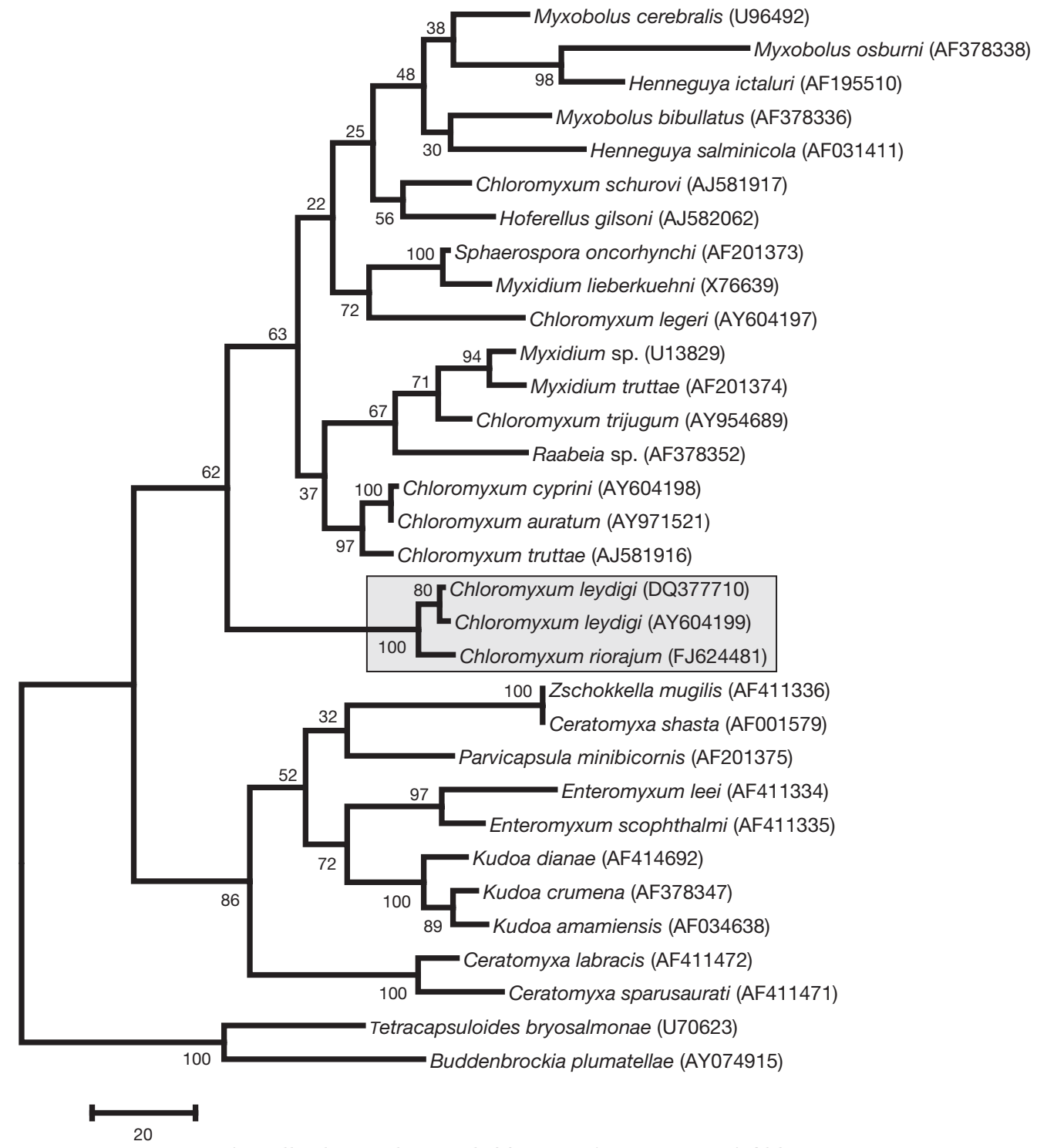

Fig. 21. Maximum parsimony tree of small subunit ribosomal (SSU) rDNA sequences of Chloromyxum riorajum sp. nov. and other selected myxosporean species. Numbers on the branches are bootstrap confidence levels on 100 replicates. GenBank accession numbers in parentheses after the species names; scale is given under the tree. C. riorajum and $C$. leydigi are placed in the basal clade with several freshwater myxosporean species (shaded box) 
al. 2006). The bootstrap for the 2 Chloromyxum species both found in the gall gladder of cartilaginous fishes, C. leydigi and Chloromyxum sp. described here, is $100 \%$ supported, and the pairwise sequence analyses presented 97.7 to $97.9 \%$ similarity (Table 2).

Most genera present in the myxosporean SSU rDNA tree are poly/paraphyletic (Kent et al. 2001). Presently, 8 sequences of Chloromyxum species are known, and the data suggest that they are paraphyletic groups. Monophyly was only observed in some freshwater Chloromyxum species, C. auratum, C. cyprini, and C. truttae, and were supported by a bootstrap value of $94 \%$. Previously phylogenetic analysis clearly shows a division into 2 clades, namely freshwater and marine species (Kent et al. 2001). One possible justification for this is the presence of numerous insertions in the V7 region of the SSU rDNA of all freshwater myxosporeans which have longer sequences than marine species. The exception are C. leydigi (Fiala \& Dyková 2004, Holzer et al. 2006) and the species we describe, $C$. riorajum sp. nov. These 2 species have marine cartilaginous fishes as hosts and do not have insertions near the 3 '-end of the SSU rDNA gene, but they are clustered with freshwater myxosporeans. For this reason, they are basal species in the freshwater myxosporean clade (Fiala \& Dyková 2004).

Additional parsimony analyses of SSU rDNA gene sequences support a close relationship between the different Chloromyxum species, as well as a very good bootstrap (100\%) for the clade to which $C$. leygidi and C. riorajum belong (Fig. 21). In conclusion, molecular phylogenetic analysis reinforced by morphological and ultrastructural data and specificity of the host suggest that the parasite from Rioraja agassizii is a new species, named Chloromyxum riorajum sp. nov.

Acknowledgements. This work was partially supported by the Eng ${ }^{\circ}$. A. Almeida Foundation (Porto, Portugal), PhD grant from 'CESPU' (to G.C.), 'CNPq' and 'CAPES'-Brazil. We thank Prof. M. Martins (UFSC-Florianópolis) for use of the facilities in his laboratory and the technical assistance of G. Ribeiro MSc (NEMAR - Florianópolis-Brazil) and J. Carvalheiro (ICBAS/UP). This work complies with the current laws of the countries in which it was performed. The helpful comments and suggestions of the anonymous reviewers in reviewing this manuscript are greatly appreciated.

\section{LITERATURE CITED}

Azevedo C, Balseiro P, Casal G, Gestal C and others (2006) Ultrastructural and molecular characterization of Haplosporidium montforti sp. nov., parasite of the European abalone Haliotis tuberculata. J Invertebr Pathol 92:23-32

Baska F (1990) Chloromyxum inexpectatum sp. nov. and Sphaerospora colomani sp. nov. (Myxozoa, Myxosporea), parasites of the urinary system of the starlet, Acipenser ruthenus. Syst Parasitol 16:185-193
Baska F (1993) Light and electron microscopic studies on the development of Sphaerospora colomani Baska, 1990 and Chloromyxum inexpectatum Baska, 1990. Acta Vet Hung 41:59-72

Casal G, Garcia P, Matos P, Monteiro E, Matos P, Azevedo C (2009) Fine structure of Chloromyxum menticirrhi sp. nov. (Myxozoa) infecting the urinary bladder of the marine teleost Menticirrhus americanus (Sciaenidae) in southern Brazil. Eur J Protistol 45:139-146

Cellere EF, Cordeiro N, Adriano ES (2002) Myxobolus absonus sp. n. (Myxozoa: Myxosporea) parasitizing Pimelodus maculatus (Siluriformes: Pimelodidae), a South American freshwater fish. Mem Inst Oswaldo Cruz 97: $79-80$

Cunha AM, Fonseca O (1918) Sobre os mixosporídios dos peixes brasileiros. Bras Med 32:393

Duncan AE, Garner MM, Bartholomew JL, Reichard TA, Nordhausen RW (2004) Renal myxosporidiasis in Asian horned frog (Megophrys nasuta). J Zoo Wildl Med 35:381-386

Fiala I (2006) The phylogeny of Myxosporea (Myxozoa) based on small subunit ribosomal RNA gene analysis. Int $\mathrm{J}$ Parasitol 36:1521-1534

Fiala I, Dyková I (2004) The phylogeny of marine and freshwater species of the genus Chloromyxum Mingazzini, 1890 (Myxosporea: Bivalvulida) based on small subunit ribosomal RNA gene sequences. Folia Parasitol 51: 211-214

Gioia I, Cordeiro NS (1996) Brazilian Myxosporidians checklist (Myxozoa). Acta Parasitol 35:137-149

Hallett SL, Atkinson SD, Holt RA, Banner CR, Bartholomew JL (2006) A new myxozoan from feral goldfish (Carassius auratus). J Parasitol 92:357-363

Hillis DM, Dixon MT (1991) Ribosomal DNA: molecular evolution and phylogenetic inference. Q Rev Biol 66: 411-453

Holzer AS, Sommerville C, Wooden R (2004) Molecular relationships and phylogeny in a community of myxosporeans and actinosporeans based on their 18S rDNA sequences. Int J Parasitol 34:1099-1111

> Holzer AS, Sommerville C, Wooden R (2006) Molecular identity, phylogeny and life cycle of Chloromyxum schurovi Shul'man and Ieshko, 2003. Parasitol Res 99:90-96

Kent ML, Andree KB, Bartholomew JL, El-Matbouli M and others (2001) Recent advances in our knowledge of the Myxozoa. J Eukaryot Microbiol 48:395-413

Kovaljova AA (1988) Myxoporidia of the genus Chloromyxum (Cnidospora, Myxosporea) of cartilaginous fishes from the Atlantic coast of Africa. Parazitologiya 22:384-388 (in Russian with English summary)

Kuznetsova IG (1977) Myxosporidians of Chondrostei from the Patagonian shelf. Parazitologiya 11:74-77

Lom J, Dyková I (1992) Myxosporidia (Phylum Myxozoa). In: Lom J, Dyková I (eds) Protozoan parasites of fishes. Elsevier, Amsterdam

Lom J, Dyková I (1993) Scanning electron microscopic revision of common species of the genus Chloromyxum (Myxozoa: Myxosporea) infecting European freshwater fishes. Folia Parasitol 40:161-174

Lom J, Dyková I (2006) Myxozoan genera: definition and notes on taxonomy, life-cycle terminology and pathogenic species. Folia Parasitol 43:1-36

Lom J, Noble ER (1984) Revised classification of the class Myxosporea Bütschli, 1881. Folia Parasitol 31:193-205

> Lom J, Dyková I, Kepr T (1988) Species of the genus Chloromyxum Mingazzini (Myxozoa: Myxosporea) infecting burbot (Lota lota L.). Syst Parasitol 11:231-237 
Molnár K (1992) Ceratomyxa hungarica sp. nov. and Chloromyxum proterorhini sp. nov. (Myxozoa, Myxosporea) from the freshwater gobi Proterorhinus marmoratus (Pallas). Syst Parasitol 22:25-31

Oliva ME, Castro RE, Burgos R (1996) Parasites of the flatfish Paralichthys adspersus (Steindachner, 1867) (Pleuronectiformes) from Northern Chile. Mem Inst Oswaldo Cruz 91: 301-306

Pinto C (1928) Mixosporídeos e outros protozoários intestinais observados na América do Sul. Arch Inst Biol 1: 101-126

Shul'man BS, Ieshko EP (2003) Chloromyxum schurovi sp. n. a new myxosporidian species (Myxosporea: Sphaerosporidae) from salmonid fishes (Salmonidae). Parazitologiya $37: 246-247$

Editorial responsibility: Sven Klimpel, Düsseldorf, Germany
Tamura K, Dudley J, Nei M, Kumar S (2007) MEGA4: Molecular evolutionary genetics analysis (MEGA) software version 4.0. Mol Biol Evol 24:1596-1599

Thompson JD, Higgins DG, Gilson TJ (1994) Clustal W: improving the sensitivity of progressive multiple sequence alignment through sequence weighting, position-specific gap penalties and weight matrix choice. Nucleic Acids Res 22:4673-4680

Whipps CM, Adlard RD, Bryant MS, Lester RJG, Findlay V, Kent ML (2003) First report of three Kudoa species from Eastern Australia: Kudoa thyrsites from Mahi mahi (Coryphaena hippurus), Kudoa amamiensis and Kudoa minithyrsites sp. nov. from sweeper (Pempheris ypsilychnus). J Eukaryot Microbiol 50:215-219

Submitted: January 15, 2009; Accepted: April 7, 2009

Proofs received from author(s): May 20, 2009 